\title{
REVIEW
}

\section{Novel therapies for acromegaly}

\author{
Bernardo Maia', Leandro Kasuki ${ }^{1,2,3}$ and Mônica R Gadelha ${ }^{1,2,4}$ \\ ${ }^{1}$ Neuroendocrinology Research Center/Endocrinology Division - Medical School and Hospital Universitário Clementino Fraga Filho - Universidade Federal \\ do Rio de Janeiro, Rio de Janeiro, Brazil \\ ${ }^{2}$ Neuroendocrinology Division - Instituto Estadual do Cérebro Paulo Niemeyer, Rio de Janeiro, Brazil \\ ${ }^{3}$ Endocrinology Division - Hospital Federal de Bonsucesso, Rio de Janeiro Brazil \\ ${ }^{4}$ Neuropatology and Molecular Genetics Laboratory - Instituto Estadual do Cérebro Paulo Niemeyer, Rio de Janeiro, Brazil
}

Correspondence should be addressed to M R Gadelha: mgadelha@hucff.ufrj.br

\begin{abstract}
Acromegaly is a systemic disease associated with increased morbidity and mortality. Most of these comorbidities can be prevented or delayed with adequate disease treatment.

Although three modalities of treatment (surgery, medical treatment, and radiotherapy) are available and new drugs were approved in the last decades, there are still some patients that maintain disease activity despite treatment. Therefore, there is a need for novel therapies for acromegaly and for that purpose new formulations of currently used drugs and also new drugs are currently under study. In this review, we summarize the novel therapies for acromegaly.
\end{abstract}

Key Words

- acromegaly

\section{Introduction}

Acromegaly is a chronic systemic rare disease most commonly caused by a somatotroph pituitary adenoma with autonomous overproduction of growth hormone $(\mathrm{GH})$ and a consequent increase in insulin-like growth factor type I (IGF-I) levels produced mainly by the liver (1). Clinical manifestations include somatotrophic effects (acral enlargement, facial alterations, arthralgia), cardiovascular, respiratory, metabolic complications and a possible increase in some neoplasias (2). If left untreated, acromegaly results in an increased morbimortality with a significant decrease in quality of life and an average 10-year reduction in life expectancy (3, $4,5)$. Disease control by reducing $\mathrm{GH}$ to $<1 \mu \mathrm{g} / \mathrm{L}$ and normalizing IGF-I restores mortality to normal rates of the general population $(2,4)$. In addition to biochemical control, treatment aims to prevent tumor growth or, ideally, induce tumor shrinkage. Currently, treatment of acromegaly includes neurosurgery, medical therapy and radiotherapy $(4,6,7)$.

\section{Current treatments}

\section{Surgical treatment}

Surgery is the gold standard treatment of acromegaly since it represents the only therapy capable of rapidly curing acromegaly (4). With experienced pituitary surgeon, transsphenoidal surgery results in a remission rate of approximately $85 \%$ for microadenomas and $40-60 \%$ for macroadenomas $(8,9)$. Several factors are predictors of surgical success: tumor size and invasiveness, preoperative GH level, patient's gender and the surgeon's experience $(10,11,12)$.

\section{Medical treatment}

Medical treatment plays an important role in acromegaly as an adjuvant therapy, since surgical cure is achieved in a fraction of patients, or as primary therapy, since few patients have clinical contraindications or refuse to be submitted to surgery $(4,10)$. Currently, there are

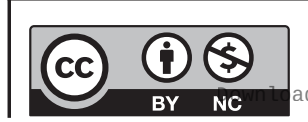

This work is licensed under a Creative Commons Attribution-NonCommercial 4.0 International License. ded from Bioscientifica.com at 04/26/2023 01:12:37PM 
Table 1 Currently approved medical therapies for acromegaly.

\begin{tabular}{|c|c|c|c|c|}
\hline Drug & Mechanism of action & Dosage & $\begin{array}{l}\text { Biochemical } \\
\text { efficacy }(\%)\end{array}$ & $\begin{array}{l}\text { Effect on } \\
\text { tumor mass }\end{array}$ \\
\hline $\begin{array}{l}\text { Octreotide long-acting } \\
\text { release }(4,14)\end{array}$ & $\begin{array}{l}\text { Somatostatin } \\
\text { receptor ligand } \\
\text { (higher SST2 affinity) }\end{array}$ & 10-40 mg/month, IM & $30-40$ & $\begin{array}{l}\text { Tumor } \\
\text { shrinkage } \\
(66 \%)\end{array}$ \\
\hline $\begin{array}{l}\text { Lanreotide autogel } \\
\qquad(4,14)\end{array}$ & $\begin{array}{l}\text { Somatostatin } \\
\text { receptor ligand } \\
\text { (higher SST2 affinity) }\end{array}$ & $\begin{array}{l}\text { 60-120 mg/month, } \\
\text { deep SC }\end{array}$ & $30-40$ & $\begin{array}{l}\text { Tumor } \\
\text { shrinkage } \\
(62.9 \%)\end{array}$ \\
\hline Pasireotide $(4,18,62)$ & $\begin{array}{l}\text { Somatostatin } \\
\text { receptor ligand } \\
\text { (higher SST5 affinity) }\end{array}$ & 40-60 mg/month, SC & 54 & $\begin{array}{l}\text { Tumor } \\
\text { shrinkage } \\
(80 \%)\end{array}$ \\
\hline Cabergoline $(4,22,26)$ & $\begin{array}{l}\text { Dopamine receptor } \\
\text { agonist }\end{array}$ & $\begin{array}{l}\text { 1.5-3.5 mg/week, PO } \\
\text { (by mouth) }\end{array}$ & 18 & $\begin{array}{l}\text { Tumor } \\
\text { shrinkage } \\
(33 \%)\end{array}$ \\
\hline Pegvisomant $(4,24)$ & GHR antagonist & 10-40 mg/day, sc & 70 & No effect \\
\hline
\end{tabular}

Gastrointestinal, injection-site reactions

Gastrointestinal, injection-site reactions

Hyperglycemia, gastrointestinal, injection-site reactions

Gastrointestinal, nasal

congestion, fatigue, orthostasis, headache, cardiac valve abnormalities Injection-site reactions, elevated liver enzymes

GHR, growth hormone receptor; IM, intramuscular; SC, subcutaneous; SST, somatostatin receptor.

three classes available for the treatment of acromegaly: somatostatin receptor ligands (SRLs), dopamine agonists, and $\mathrm{GH}$ receptor antagonist $(4,7,10)$ (Table 1$)$.

\section{Somatostatin receptor ligands}

Somatostatin receptor ligands are the most frequently prescribed therapy and there are three different available drugs in this class, divided into two generations: firstgeneration SRLs (fg-SRLs), represented by octreotide longacting release (OCT-LAR) and lanreotide autogel, that are considered first-line therapy; and second-generation SRL, represented by pasireotide (PAS) (13). Both fg-SRLs, in real-life, seem to be equally effective in controlling $\mathrm{GH}$ and IGF-I levels in approximately $30-40 \%$ of patients (14). In patients well controlled with low dose fg-SRL, extended dose intervals can be tried with the majority of patients maintaining disease control (15). Pasireotide is a multi-somatostatin-receptor ligand with affinity for somatostatin receptors (SST) 1, 2, 3 and mainly to 5 . The fg-SRLs preferentially bind to SST2. Pasireotide has been demonstrated to provide superior clinical efficacy over fg-SRLs in both treatment-naïve patients and in those inadequately controlled with fg-SRLs $(16,17)$. In a reallife study, IGF-I normalization was achieved in 54\% of patients with acromegaly that were not controlled with fg-SRLs (18). However, pasireotide may also cause a worsening of glucose homeostasis, a less frequent adverse effect with the use of fg-SRLs $(16,17,19,20)$.

\section{Dopamine agonists}

Dopamine agonists, represented by cabergoline, have a modest efficacy in acromegaly and plays a role as adjunctive therapy in cases with mildly elevated IGF-I levels ( $<2.5$ times the upper limit of normal (ULN)) (7, 21,22 ). Long-term disease control is observed in $18 \%$ for patients in monotherapy (22).

\section{Pegvisomant}

Pegvisomant (PEGV) is a selective growth hormone receptor antagonist usually administered as second-line therapy, achieving biochemical control rates of $90 \%$ or more in clinical trials (23) and a real-life control rate of approximately 70\% (24). Nevertheless, compliance (daily injections), side effects (hepatotoxicity, injection site reactions), inadequate up-titration and not having a tumor-suppressive effect limit its use. Another nonmedical factor that limits its use in some countries is the difficulty of access due to cost-effectiveness issues (25).

\section{Combination therapy}

As evidenced previously, monotherapy is not able to achieve complete biochemical control in a considerable number of patients in clinical practice, requiring combined drug administration to improve clinical outcomes. In these cases of partial response, combined medical treatment may have the benefit of reducing side effects associated with an individual higher dose medication by decreasing the frequency of injections and/or total drug dose $(4,21)$. Combinations used in acromegaly treatment are: fg-SRL+cabergoline (allowing disease control in approximately $23 \%$ of patients); fg-SRL+PEGV and PEGV + cabergoline that allows disease control in similar rates to PEGV monotherapy, but with additional benefits

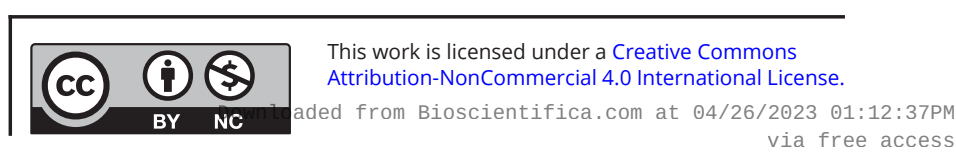


of action in the tumor and allowance of lower PEGV doses $(4,22,26,27,28,29)$.

\section{Other drug therapies}

In addition to the aforementioned three classes of drugs for the treatment of acromegaly, there are also others medical therapies, reserved in special situations.

Oral estrogens and selective estrogen receptor modulators (SERMs) are capable of reducing IGF-I levels through modulating $\mathrm{GH}$ responsiveness, by inducing SOCS2 expression and thereby negatively inhibiting the GHR-JACK2-STAT5 signaling pathway (30). This so-called first-pass effect may be seen in patients with acromegaly when used alone or in combination with an SRL or cabergoline (31). Nevertheless, these medications are not part of the regular acromegaly management arsenal and further studies are necessary to demonstrate their real effectiveness and safety.

Temozolomide is an alkylating agent that induces DNA damage, causing the death of tumor cells (32). It is a chemotherapy reserved for aggressive pituitary tumors and pituitary carcinomas, refractory to the aforementioned conventional therapy (32).

\section{Radiation therapy}

Radiation therapy (RT) is usually considered a third-line option, reserved as an adjuvant therapy for patients with aggressive tumors who failed surgical and medical treatment $(4,6)$. The effects of RT are not immediate and biochemical remission may be achieved only after 5-15 years, requiring the use of drugs in the interim (33). Remission rates of $50-70 \%$ have been reported with stereotactic radiotherapy in patients followed up to 15 years $(33,34,35)$. The great disadvantage of this method that places it as a last-line therapy is the frequent occurrence of complications, such as hypopituitarism (10-50\% of patients within 5-10 years), cognitive changes, radiation-induced cranial nerve damage, cerebrovascular disease, secondary tumors and radionecrosis $(33,34,35)$.

\section{Novel therapies}

The current clinical management of acromegaly is far from ideal, since biochemical control is not achieved in all patients; adverse events may be critical in some individuals, leading to intolerance and limited use; and except for DA, all frequently used drugs require regular injections, which could reduce the quality of life $(36,37)$. In recent years, novel therapies have been studied in preclinical and clinical trials, and in the year 2020, one of them was approved for clinical treatment. While some of them correspond to new therapeutic agents, others represent new SRLs with different routes of administration or even a novel combination of already existing drugs (Table 2).

\section{New combination of drugs already approved}

\section{Pasireotide and pegvisomant}

Pasireotide and PEGV are two of the most effective drugs already used for medical therapy in acromegaly, but their combined treatment has not been extensively studied. Potential benefits of this combination could be a reduction in the PEGV dose, reflecting a reduction in the total cost of treatment; reduction of glucose abnormalities associated with PAS monotherapy; and biochemical control of acromegaly resistant to conventional medical therapy.

The PAPE study is currently the only published trial that aimed to assess efficacy and safety of PAS alone or in combination with PEGV by switching patients with acromegaly who were well controlled with fg-SRLs and PEGV to PAS with or without PEGV (38). It is a 24-week, prospective, single-center, open-label, investigatorinitiated study involving 61 well-controlled (defined as an IGF-I $\leq 1.2 \times$ ULN) acromegaly patients that had received weekly PEGV and monthly injections of either OCT-LAR $30 \mathrm{mg}$ or lanreotide autogel $120 \mathrm{mg}$ for at least 6 months prior to study entry. At baseline, fg-SRL treatment was continued, and the PEGV dose was reduced by 50\% up to 12 weeks. When IGF-I levels remained $\leq 1.2 \times$ ULN after 12 weeks, subjects were switched to PAS $60 \mathrm{mg}$ monotherapy every 4 weeks. When IGF-I levels exceed $1.2 \times$ ULN after 12 weeks, patients were switched to PAS $60 \mathrm{mg}$ and continued with 50\% reduced PEGV dose. Between the 12 and 24 weeks period, PEGV dose alteration was not permitted unless IGF-I decreased below the age-adjusted normal limits. In these cases, the PEGV dose was reduced by $20 \mathrm{mg}$ weekly until IGF-I levels reached their normal values (38). At baseline, the mean IGF-I was 0.97× ULN (95\% CI, 0.91-1.02) with a mean PEGV dose of $134 \mathrm{mg} /$ week (95\% CI, 103-166). At 12 weeks, the mean IGF-I level increased to $1.59 \times$ ULN (95\% CI, 1.45-1.73) and IGF-I $\leq 1.2 \times$ ULN was observed in $24.6 \%$ patients, so they were switched to the PAS monotherapy arm, by protocol. At 24 weeks, IGF-I levels were reduced into the reference

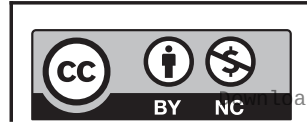

This work is licensed under a Creative Commons Attribution-NonCommercial 4.0 International License. ded from Bioscientifica.com at 04/26/2023 01:12:37PM 
Table 2 Novel medical therapies for acromegaly.

\begin{tabular}{|c|c|}
\hline Drug & $\begin{array}{l}\text { Mechanism of } \\
\text { action }\end{array}$ \\
\hline Pasireotide + Pegvisomant (38) & $\begin{array}{l}\text { Somatostatin } \\
\text { receptor } \\
\text { ligand + GHR } \\
\text { antagonist }\end{array}$ \\
\hline
\end{tabular}

\begin{tabular}{|c|c|}
\hline $\begin{array}{l}\text { Clinical trial } \\
\text { phase }\end{array}$ & Dosage \\
\hline Phase 4 & $\begin{array}{l}\text { Pasireotide } 60 \text { mg IM } \\
\text { monthly + Pegvisomant } \\
21-78 \text { mg SC weekly }\end{array}$ \\
\hline
\end{tabular}

\begin{tabular}{l} 
Biochemical \\
efficacy $(\%)^{\mathrm{a}}$ \\
\hline
\end{tabular}

73.8 21-78 mg SC weekly

\section{Oral octreotide formulation (46)}

Paltusotine ClinicalTrials.gov Identifier: NCT03789656 NCT03792555

NCT04261712

ATL1103 (51)

\section{Somatostatin receptor 2 ligand \\ Somatostatin receptor 2 biased agonist}

Antisense
oligonucleotide
inhibitor of GHR

Phase 2 completed

\section{Phase 3 completed (recently FDA approved) \\ Phase 2 (active} stage)

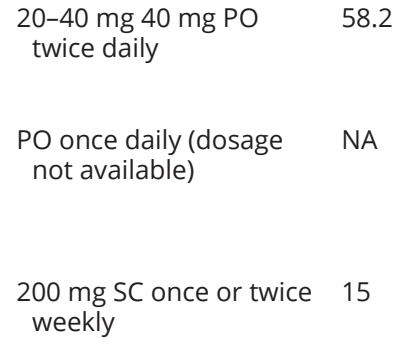

58.2

NA

15

NA

$\begin{array}{cc}\text { Antisense } & \text { Phase } 2 \\ \text { oligonucleotide } & \text { (recruitment } \\ \text { inhibitor of GHR } & \text { stage) }\end{array}$

Single SC doses 28-28 NA days (dosage not available)

\section{ClinicalTrials.gov Identifier: NCT03548415}

\begin{tabular}{l} 
Effect on \\
tumor mass \\
\hline $\mathrm{NA}$
\end{tabular}

Main side effects

Hyperglycemia, new-onset diabetes, gastrointestinal, myalgia, fatigue, headache, arthralgia, dizziness Gastrointestinal, blood glucose increase

NA

${ }^{a}$ Attention to the different criteria of biochemical control between studies, specified in the text.

GHR, growth hormone receptor; IM, intramuscular; NA, not available; PO, per os (by mouth); SC, subcutaneous.

range in $93.3 \%$ of patients in the PAS monotherapy group and in $67.4 \%$ of patients in the combination group. Between baseline and 24 weeks, the mean PEGV dose could be decreased to $48 \mathrm{mg} /$ week (95\% CI, 21-74), whereas PEGV could be discontinued in $67.8 \%$ of patients (38). The most common adverse effect recorded was hyperglycemia $(88.5 \%)$ with a frequency of diabetes mellitus (DM) increasing from $32.8 \%$ at baseline to $68.9 \%$ at 24 weeks. Baseline HbA1c was the main predictor of DM development at the end of the trial (38). This data indicated that PEGV was not able to compensate the hyperglycemia induced by PAS, probably due to the mechanism of action of the drugs: PEGV improves insulin sensitivity by antagonizing GH action, while the hyperglycemic effect of PAS is related to inhibition of insulin production by $\beta$-pancreatic cells, in addition to suppression of incretins, regardless of insulin resistance $(38,39)$.

This study demonstrated that PAS is a possible treatment option in patients previously controlled with the combination of fg-SRL and PEGV. This switch of SRL therapy has an important PEGV-sparring effect and a consequent reduction in the total cost of therapy. However, despite the high efficacy and supposed cost reduction, there is an increased risk of developing DM and health care costs related to this (38). Therefore, it is necessary to carefully choose the patients that would benefit the most from this new combination treatment, requiring further long-term studies.

In line with this, the PAPE extension study presented long-term 48 weeks results of efficacy and safety of PAS alone or in combination with PEGV treatment in acromegaly (40). It was a prospective, open-label, singlecenter follow-up study until 48 weeks after the core trial of 24 weeks, enrolling 59 out of 61 patients of the original study. At the end of the study, $77 \%$ of patients achieved normal IGF-I levels $(\leq 1.2 \times$ ULN) with a mean IGF-I of $0.98 \times$ ULN (95\% CI, 0.90-1.06). Stratifying for each treatment arm, $93.3 \%$ of subjects in the PAS monotherapy group had IGF-I normalization at 24 weeks, which was sustained at 48 weeks; while $67.4 \%$ of patients in the combination treatment group achieved IGF-I normalization at 24 weeks, which increased to $71.7 \%$ at 48 weeks (40). During extension, phase mean PEGV dose had to be increased from 47 to $64 \mathrm{mg} /$ week (95\% CI, 33-95), but with an overall cumulative PEGV dose reduction of $52 \%$ after 48 weeks compared to baseline, and $50.8 \%$ of patients were off PEGV treatment at the end of the trial, confirming PEGV-sparring effect of PAS (40).

Hyperglycemia remained the most common and important adverse event during the study, with an incidence of DM that increased from $68.9 \%$ at 24 weeks

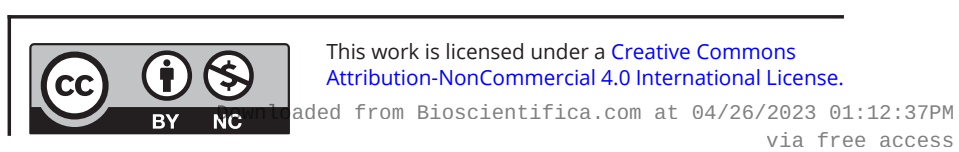


to $77 \%$ at 48 weeks. PAS-induced hyperglycemia was inversely correlated with baseline insulin secretion, indicating that the lower the insulin secretion at baseline, the greater will be the risk of hyperglycemia during treatment. No significant difference was observed in HbA1c levels between patients using PAS monotherapy and combination treatment at baseline $(P=0.36)$, 24 weeks $(P=0.72)$, and after 48 weeks $(P=0.26)(40)$. This extension study corroborates previously published data, which shows that PAS biochemically controls a large part of acromegaly patients with a 50\% PEGV-sparring effect. However, it is associated with a high incidence of DM, which appears to be inversely related to the pancreatic $\beta$-cell ability to secrete insulin before starting treatment (40).

In addition, a recent study demonstrated the effectiveness of the synergistic action of the combination therapy PAS and PEGV in achieving biochemical control in six acromegaly patients resistant to all conventional medical treatments (41). The control group included 49 patients resistant to fg-SRL, but that were controlled with PAS (as monotherapy) or PEGV (as monotherapy or combined with fg-SRLs). The six patients in the study group were submitted to first-line treatment with pituitary neurosurgery, with except of only one patient due to technical difficulties with intubation and anesthesia induction. Because of tumor invasiveness characteristics and subtotal resection of the adenomas, all these patients received treatment with fg-SRL. Complete resistance was observed in all six patients and, consequently, this group was treated with second-line drugs, including combination therapy with fg-SRL and PEGV in two patients, PAS as monotherapy in three of them, and in one of the patients both treatments were tried. A second neurosurgery was performed on four of these six patients, seeking tumor debulking. After the failure of all other treatments, biochemical control of acromegaly was achieved in all 6 patients through combination therapy with PAS and PEGV. Regrowth of the residual tumor was not observed, and one patient presented a reduction of the lesion. A worsening of glycemic control occurred in one patient with previously DM, and new-onset impaired glucose tolerance was diagnosed in another, but these adverse effects were improved with the adjustment of previous insulin therapy and the introduction of a hypocaloric hypoglycidic diet, respectively. It is important to note that the study group was composed of tumors with a bad biochemical-radiological-histological prognosis, with higher GH levels, larger tumor dimensions and invasive nature, higher proliferative index (Ki-67) expression, and histopathological pattern of resistance to fg-SRL (low SST2 expression and low SST2/SST5 ratio). Albeit this study has a main limitation of the small sample size, it reinforces the important concept of personalized treatment in acromegaly, presenting a new possibility of combining medications for the control of aggressive disease (41).

\section{New drugs from existing classes}

\section{Octreotide capsule}

An oral formulation of octreotide capable of replacing the current medical treatment of acromegaly that requires lifelong use of parenteral drugs represents an interesting perspective on disease treatment for many patients. When administered orally, octreotide is mainly absorbed as an intact peptide in the jejunum, however the intestinal mucosa barrier, unfortunately, decreases its absorption, resulting in low plasma levels and low bioavailability (42).

The oral formulation of octreotide bypass this limitation with the introduction of transient permeability enhancer (TPE) technology, which can improve drug absorption through a transient and reversible opening of epithelial tight junctions in the small intestine, leading to high intestinal permeability (43). The tight junctions correspond to a transmembrane protein complex with an intestinal barrier function in relation to paracellular permeability of water-soluble macromolecules (43). Its function is dynamically regulated by a physiological extracellular stimuli, with an increase in permeability through, for example, bile salts and medium chain fatty acids (43). Octreotide capsule contains the TPE

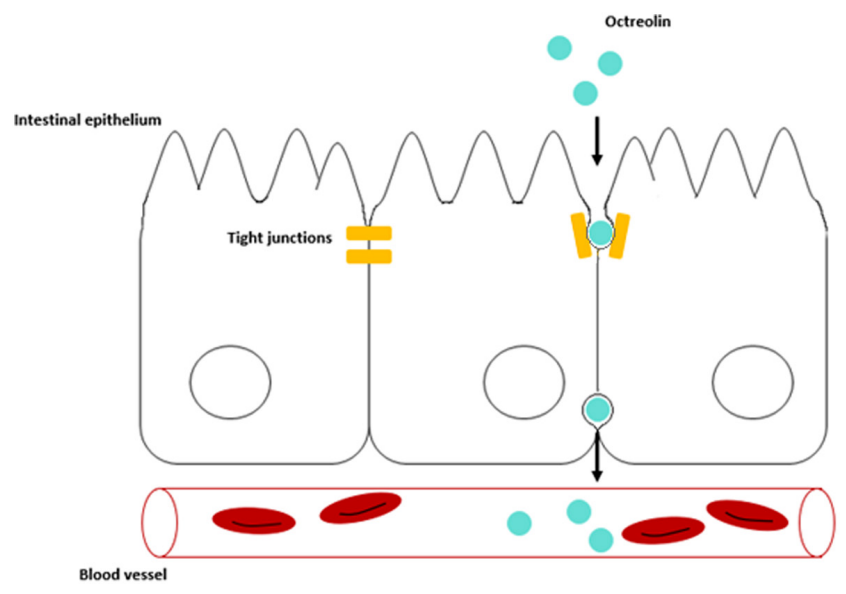

Figure 1

Mechanism of action of Octreolin. Octreotide capsules with transient permeability enhancer (TEP) technology, promotes a transient and reversible opening of epithelial tight junctions, crossing the intestinal barrier. This process improves the absorption of the drug and allows a serum therapeutic level of octreotide.

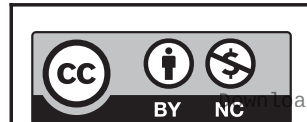

This work is licensed under a Creative Commons Attribution-NonCommercial 4.0 International License. ded from Bioscientifica.com at $04 / 26 / 2023$ 01:12:37PM 
technology which consists of a combination of medium chain fatty acid sodium salt with the drug peptide in an oily suspension in an enteric coating (Fig. 1) (43).

In preclinical studies, the pharmacokinetic profile in rats and primates demonstrated similar serum levels of octreotide after administration of oral capsules and SC injection, resulting in rapid and sustained suppression of GH levels in both administration models (43). This result demonstrates that the oral route retained the biological inhibitory activity of octreotide. Primate studies have shown safety without organ damage and a comparable toxicity profile between the octreotide capsule and injected dose (43). Intestinal permeability was demonstrated in rat models by fluorescent tracers showing that TPE transiently enhances permeability via paracellular transport by a rearranging of tight junctions proteins (ZO-1) in rats intestine (43). Intestinal permeability returned to baseline levels in 1-1.5 $\mathrm{h}$ after drug ingestion (43). Another important aspect demonstrated in the rat model was the inverse relationship between intestinal permeability and the molecule to be absorbed, with the best absorption presented with smallest dextrans molecules (4 kDa) coupled with TPE (43). Larger dextrans (40-70 kDa) were minimally absorbed, limiting the risk of internalization of intestinal pathogens and immunoglobulins (43). Limitation of time and size on intestinal permeability with TPE are two important aspects to favor safety in healthy individuals.

A phase 1 study was conducted in 75 healthy subjects using single doses (3, 10, $20 \mathrm{mg})$ of an octreotide capsule (Octreolin) and a single dose of $100 \mu \mathrm{g}$ octreotide SC injection (44). Pharmacokinetics data showed that octreotide plasma concentration was dose-dependent following oral administration and a $20 \mathrm{mg}$ dose was comparable to a $100 \mu \mathrm{g}$ injection. After SC injection, octreotide reached peak levels in $0.6 \mathrm{~h}$, while oral formulation increases more slowly with a serum peak in $2.7 \mathrm{~h}$ (44). Meanwhile, plasma octreotide concentration decreased with a comparable mean half-life for both routes of administration, reaching subtherapeutic levels $(<0.5 \mu \mathrm{g} / \mathrm{mL})$ after $6 \mathrm{~h}$ with injection and after $8 \mathrm{~h}$ with oral capsule (44). Food intake and proton pump inhibitors demonstrated a pronounced effect on Octreolin absorption, with almost 90 and 40\% reduction in plasma concentration, respectively. In this study, an oral dosing of $20 \mathrm{mg}$ strongly suppressed basal GH levels, reducing average GH concentration by $44 \%$ $(P<0.05)$. In addition, $80 \%$ of $\mathrm{GH}$ secretion induced by growth hormone-releasing hormone (GHRH)-arginine stimulation was significantly suppressed $(P<0.001)$ in the
Octreolin-arm (44). Besides injection adverse effects, safety profile were comparable in both treatment groups, exhibiting an $8-15 \%$ incidence of gastrointestinal side effects and headache (44).

A phase 3 multicenter, open-label, dose-titration, case-controlled study was designed to test efficacy and safety of octreotide capsule in 155 acromegaly patients previously treated with stable doses of injectable SRLs for $\geq 3$ months and that were complete or partially controlled (IGF-I $<1.3 \mathrm{ULN}$, and 2-h integrated GH $<2.5 \mathrm{ng} / \mathrm{mL}$ ) (45). The main objective was to determine the efficacy of oral octreotide in maintaining biochemical control in patients who were prior responders to injectable SRLs. The first dose was administered 4 weeks after the last SRL injection, starting on $40 \mathrm{mg}$ ( $20 \mathrm{mg}$ twice daily, $>1 \mathrm{~h}$ before or $2 \mathrm{~h}$ after a meal). In the titration phase, doses were progressively increased to values of up to $80 \mathrm{mg}$ per day, according to IGF-I levels response, reaching a later maintenance phase with fixed doses for a core treatment of 7 months, followed by a voluntary 6 months extension. Of 102 subjects completing the core treatment, 86\% elected to continue to the extension phase (45). Of the 151 evaluable individuals in the modified intention-totreat group (all participants who had at least one efficacy assessment after first dose), 65\% showed a sustained response and reached the primary endpoint of IGF-I $<1.3$ ULN and mean integrated $\mathrm{GH}<2.5 \mathrm{ng} / \mathrm{mL}$ at end of core treatment period, and $62 \%$ at end of extension period (13 months). Effect was durable and $85 \%$ of patients who entered the fixed-dose regime maintained their response for up to 13 months (45). Predictors of degree of oral capsule responsiveness included good baseline control on injectable SRLs (IGF-I $\leq 1 \mathrm{ULN}, \mathrm{GH}<2.5 \mathrm{ng} / \mathrm{mL}$ ) and low to mid doses of injectable SRLs (OCT-LAR $<30 \mathrm{mg}$ or lanreotide autogel $<120 \mathrm{mg}$ ). Clinical control of acromegaly symptoms (headache, asthenia, perspiration, swelling of extremities and joint pain) also improved during the trial. At baseline, $81 \%$ of biochemically controlled subjects treated with SRL injections persisted with at least one active symptom of acromegaly. By the end of the fixed-dose phase, $54 \%$ of patients showed improvements and $26 \%$ maintained the severity of their symptoms (45). The most adverse effects were transient, resolved with treatment continuation, occurred at first 60 days of treatment and were not dose related. Of 155 patients, 89\% experienced adverse effects of which $92 \%$ were classified as mild to moderate. Most common side effects were gastrointestinal (nausea, diarrhea, dyspepsia, abdominal pain, flatulence, vomiting), neurological (headache, dizziness), musculoskeletal (arthralgia, back pain). 
Twenty-three participants withdrew due to adverse events, 19 of them were study drug related. Two deaths were reported, but both were unrelated to the drug. Side effects were consistent with the already known SRL profile and acromegaly disease burden, with no safety signal related to the novel formulation and route of administration (45).

Oral octreotide was also evaluated in a 9-month phase 3 double-blind, randomized, placebo-controlled, multicenter study designed to evaluate efficacy and safety of octreotide capsule in acromegaly patients who demonstrated biochemical control on injectable SRL treatments (46). In this trial, 56 patients with acromegaly previously controlled (IGF-I $\leq 1.0 \times$ ULN based on the average of two assessments) with injectable fg-SRL (on a stable dose for $\geq 3$ months of therapy and using it for $\geq 6$ months) were switched for oral octreotide or placebo. Normalization of IGF-I levels was maintained in 58\% of patients treated with oral octreotide in comparison with $19 \%$ in the placebo group $(P=0.0079)(46)$. On June 26, 2020, FDA approved oral octreotide capsules as the first oral SRL for long-term maintenance treatment in patients with acromegaly who have responded to and tolerate treatment with injectable SRLs. This represents an improvement in the treatment arsenal of acromegaly, adding an effective and safe oral medication, an alternative for a significant proportion of patients from chronic injecting drug treatment.

\section{Somatostatin receptor 2 biased agonist}

Another emerging treatment is paltusotine (formerly known as CRN00808), an oral selective nonpeptide SST2 biased agonist. The term biased agonism reflects the ability of a ligand to selective activates a subset of a receptor's signaling pathway, different from other ligands $(47,48)$. In 2018, a phase 1 , double-blind, randomized, placebo-controlled, single- and multiple-ascending dose trial was designed to evaluate safety, pharmacokinetics, pharmacodynamics and potential interaction with midalozam of this drug in 99 healthy volunteers (ClinicalTrial.gov Identifier: NCT03276858) (49). The data indicated that the drug was well absorbed with a half-life of $42-50 \mathrm{~h}$, supporting once daily administration. The steady-state was reached in 3-5 days. Systemic exposure was markedly reduced when the capsule was taken with food, demonstrated as lower plasma CRN00808 area under curve (83\%). Oral administration resulted in dose-dependent suppression of both GHRH stimulated GH and IGF-I secretion. Maximum GH-axis suppression was observed with $10 \mathrm{mg}$ dose. Co-administration of midazolam in the drug interaction arm was performed to assess risk of interaction with CYP3A4/5 substrate, and results showed no midazolam pharmacokinetic changes with $20 \mathrm{mg}$ of CRN00808, meaning little or no risk profile. Treatment adverse events were consistent with already known SRL profile and were generally mild and transient. Approximately 30\% of subjects presented with gastrointestinal effects and mild elevations of pancreatic enzymes were reported in about $10 \%$ of participants. There was no serious event related to medication (49).

There are currently two active phase 2 clinical trials evaluating paltusotine in acromegaly. The ACROBAT EDGE is an open label exploratory study designed to evaluate the safety, efficacy, and pharmacokinetics of this drug in subjects with acromegaly that are treated with SRL regiments but do not respond completely to monotherapy (ClinicalTrials.gov Identifier: NCT03789656). The ACROBAT EVOLVE is a doubleblind, placebo-controlled, randomized withdraw study to evaluate the safety, efficacy and pharmacokinetics of paltusotine compared to placebo in patients with acromegaly that respond to OCT-LAR or lanreotide depot monotherapy (ClinicalTrials.gov Identifier: NCT03792555). The EVOLVE and EDGE studies are conducted at the same centers globally and patients that complete either trial will be eligible to participate in an open-label extension study (ACROBAT ADVANCE). The ADVANCE is a phase 2, open label, long-term extension study designed to evaluate the safety and efficacy of paltusotine in acromegaly (ClinicalTrials.gov Identifier: NCT0461712).

\section{New class of drugs}

\section{Antisense oligonucleotide}

Antisense oligonucleotides are a single-stranded synthetic nucleotide sequence that binds to a specific mRNA, inhibiting the transcription of the gene and thus protein synthesis (50). ATL1103 is an antisense oligomer drug designed to block GHR expression, thereby lowering IGF-I levels (51). It has a chimeric arrangement consisting of a DNA core (or 'gap') of 20 nucleotides with a phosphorothioate backbone and flanked by 2'-O-methoxyethyl modifications of the terminal five nucleotides at each end, resulting in an increased plasma half-life and affinity for the mRNA (52). Thus, ATL1103 forms a complex with GHR mRNA and activates RNase $\mathrm{H}$, which cleaves this hybrid, degrading GHR mRNA and preventing gene transcription (Fig. 2). 


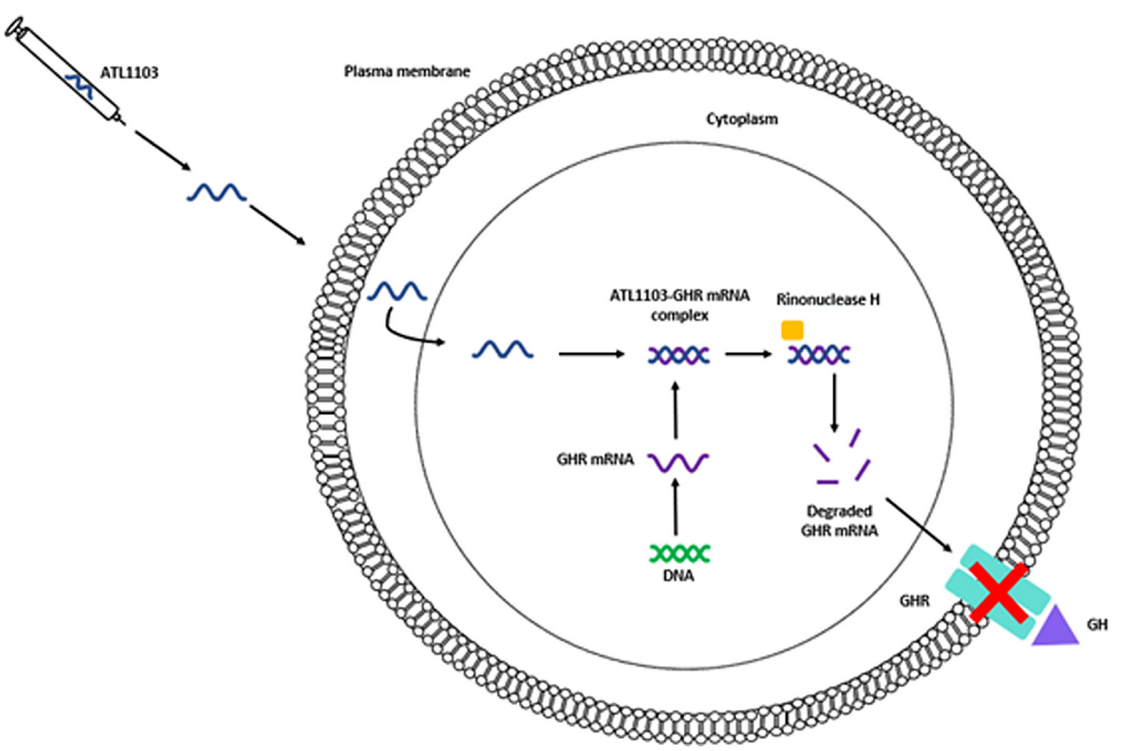

\section{Figure 2}

Mechanism of action of ATL1103. ATL1103, an antisense oligonucleotide drug, binds to growth hormone receptor (GHR) mRNA, activates ribonuclease $\mathrm{H}$, which cleaves this complex, degrading the GHR mRNA. This process blocks gene transcription, inhibits the synthesis of $\mathrm{GH}$-receptor (GHR) and, consequently, its binding to $\mathrm{GH}$, ultimately decreasing insulin-like growth factor type I (IGF-I) levels.

In preclinical studies, ATL227446 (later renamed ATL1103) demonstrated promising results in modulating GH signaling (53). In vitro mouse cells, it knocked down GHR mRNA by $87 \%$, and in vivo normal mice it resulted in $70 \%(P<0.0001)$ reduction of GHR mRNA levels in liver tissue. This effect of inhibiting GH signaling was evidenced by a $59 \%$ decrease in serum IGF-I levels in mice treated for 10 weeks (53).

A phase 1 randomized, placebo-controlled, doubleblind study tested subcutaneous (SC) doses of ATL1103 in 32 healthy male adults in two stages (54). In the single ascending dose stage of the trial, 24 subjects received four dose levels of ATL1103 or placebo, starting at $25 \mathrm{mg}$ and escalating to 75,250 and $400 \mathrm{mg}$. In the multiple dose stage, eight subjects received six doses of $250 \mathrm{mg}$ of ATL1103 and four participants received placebo. The treated group showed a trend of reduction in IGF-I levels from days 14 to 28 , with a statistically significantly effect $(P=0.034)$ at day 21 with a $7 \%$ reduction in mean IGF-I levels vs baseline. Levels of GH-binding protein (GHBP), which is produced by cleavage from GH-receptor, were also statistically significant reduced by $16 \%(P=0.007)$ at day 21 . Thus, this reduction provides support of the drug affinity for its target (54).

A phase 2 randomized, open-label, parallel-group study assessed the potential of ATL1103 as a treatment for acromegaly (51). Twenty-six patients with active acromegaly (IGF-I levels > 1.3 ULN at screening visit) were equally divided into two study arms, receiving $200 \mathrm{mg}$ ATL1103 once or twice weekly for 13 weeks. After completion of the drug administration period, patients were monitored for an additional 8 weeks, without acromegaly therapy. At week 14, the twiceweekly regiment resulted in a medial fall in IGF-I levels of $27.8 \%(P=0.0002)$ compared to baseline, with $2(15 \%)$ of 13 patients achieving an IGF-I level within the reference range. No change in IGF-I occurred with once-weekly dosing. In the twice-weekly cohort, IGF-I levels were still declining at week 14 and remained lower by a median of $18.7 \%(P=0.0005)$ at the end of the washout period (week $21)$. This suggests that the duration of ATL1103 study therapy was too short to achieve maximum effectiveness and prolonging treatment at the doses used could result in a greater decline in IGF-I levels. GHBP levels also showed a significant decline at week 14 , with a median decrease of 23.6 and $48.8 \%$ in the once and twice-weekly cohorts $(P=0.027$ and $P=0.005)$, respectively. These results were maintained until week 21. GH levels had increased by a median of $46 \%$ at week $14(P=0.001)$ in the twice-weekly regiment, but no change was demonstrated in the once weekly group. ATL1103 was well tolerated, although 85\% of patients in both cohorts experienced mild-to-moderate injection site reactions. Four serious adverse effects were reported, but none were felt to be drug related. There were no significant changes in pituitary tumor size, but the short duration of the study is a limitation to evaluate this effect (51).

Therefore, the current findings of ATL1103 demonstrate a proof of concept that GH-receptor antisense oligomer lowers IGF-I levels in acromegaly. It has the potential to achieve disease control, but more studies with higher doses and/or longer duration treatment are needed to determine the potential of this novel therapy.

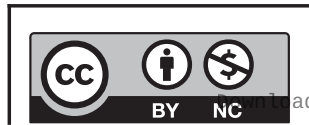

This work is licensed under a Creative Commons Attribution-NonCommercial 4.0 International License. ded from Bioscientifica.com at 04/26/2023 01:12:37PM via free access 
Currently, there are two clinical trials involving another antisense inhibitor of the GHR, both at the recruitment stage. The first one is a double-blind, placebocontrolled phase 2 study, designed to assess the safety, tolerability, and efficacy of ISIS 766720 (IONIS-GHRLRx) administered once every 28 days for 16 weeks in 60 patients with acromegaly being treated with fg-SRLs. These patients must be on stable maximum or maximally tolerated dose of fg-SRL with a serum IGF-I between 1.3 and $5 \times$ ULN, adjusted for age and sex, at screening (ClinicalTrials.gov Identifier: NCT03548415). The other clinical trial is an open-label extension trial of the same drug, including all the 60 participants that will remain on the same dose from previous study for 53 weeks. At the end of this period, participants will enter a 14-week posttreatment evaluation course (ClinicalTrials.gov Identifier: NCT03967249).

\section{Precision medicine in the treatment of acromegaly}

Considering all the available options for acromegaly treatment and all the emerging drugs under evaluation, the current treatment scenario, where the majority of patients receive the same treatment (fg-SRL) after surgical failure, can be optimized by the description of biomarkers of response, that help to identify the best drug for each individual patient. Some biomarkers have been described in the literature and several groups are working in the description of biomarkers that will allow a more individualized treatment.

For fg-SRL the most robust predictor of response is SST2 expression, with a lower chance of disease control in patients with low expression of this biomarker. In addition, other biomarkers have been described, like tumor intensity on T2-weighted sequence of MRI, pretreatment IGF-I levels, age and body weight $(55,56)$. Other molecular or pathological biomarkers have also been proposed, although they still lack standardization and reference values for clinical application $(57,58,59$, $60,61,62,63)$.

Expression of SST2 has been suggested to be a predictor of pasireotide response, but SST5 seems to be a better predictor in patients resistant to fg-SRL treatment $(60,64$, 65). However, those patients with low SST2 expression may have a better tumor shrinkage with pasireotide (66). For pegvisomant, some predictors have been described like pre-treatment GH and IGF-I levels, age and BMI (67). Expression of exon3-deleted growth receptor has been proposed as a predictor of response to pegvisomant in some studies, although it has not been confirmed in larger series $(68,69)$.

Although biomarkers have been described for different treatments of acromegaly, there is still a need for improvement in this field, especially with larger studies applying robust methodology that will allow standardization in the analysis of these biomarkers, and application in the clinical practice.

\section{Conclusion}

Acromegaly is a life-threatening disease with a great burden on the individual's quality of life when biochemical control is not achieved. Current medical therapy, while effective and relatively safe, does not achieve disease control in a proportion of patients. Therefore, novel formulations or combinations of current approved drugs and new molecules in clinical development will bring a new horizon for these cases. Advances in scientific knowledge of the characteristics of pituitary tumors (growth pattern, gene mutations, immunohistochemical aspects) and patients particular aspects (comorbidities, GH/IGF-I levels) will help to determine biomarkers of disease response allowing an individualized treatment rather than a universal algorithm approach.

\section{Declaration of interest}

M R G has received unrestricted research grants and lecture fees from Novartis, Ipsen and Pfizer; has participated on advisory boards for Novartis and Ionis; and is a PI in clinical trials by Novartis and Crinetics. $L \mathrm{~K}$ has received lecture fees from Novartis, Pfizer and Ipsen and has participated as a co-investigator in clinical trials by Novartis and Ipsen. B M has nothing to disclose.

\section{Funding}

This research did not receive any specific grant from any funding agency in the public, commercial or not-for-profit sector

\section{References}

1 Capatina C \& Wass JA. 60 YEARS OF NEUROENDOCRINOLOGY: Acromegaly. Journal of Endocrinology 2015226 T141-T160. (https:// doi.org/10.1530/JOE-15-0109)

2 Gadelha MR, Kasuki L, Lim DST \& Fleseriu M. Systemic complications of acromegaly and the impact of the current treatment landscape: an update. Endocrine Reviews 201940 268-332. (https://doi.org/10.1210/er.2018-00115)

3 Mercado M, Gonzalez B, Vargas G, Ramirez C, de los Monteros AL, Sosa E, Jervis P, Roldan P, Mendoza V, López-Félix B, et al. Successful mortality reduction and control of comorbidities in patients with

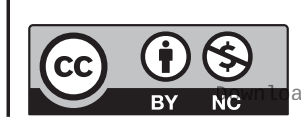

This work is licensed under a Creative Commons Attribution-NonCommercial 4.0 International License. ded from Bioscientifica.com at 04/26/2023 01:12:37PM 
acromegaly followed at a highly specialized multidisciplinary clinic. Journal of Clinical Endocrinology and Metabolism 201499 4438-4446. (https://doi.org/10.1210/jc.2014-2670)

4 Katznelson L, Laws ER, Melmed S, Molitch ME, Murad MH, Utz A, Wass JA \& Endocrine Society. Acromegaly: an endocrine society clinical practice guideline. Journal of Clinical Endocrinology and Metabolism 201499 3933-3951. (https://doi.org/10.1210/jc.20142700)

5 Melmed S. Acromegaly pathogenesis and treatment. Journal of Clinical Investigation 2009119 3189-3202. (https://doi.org/10.1172/ JCI39375)

6 Katznelson L, Atkinson JL, Cook DM, Ezzat SZ, Hamrahian AH, Miller KK \& American Association of Clinical Endocrinologists. American Association of Clinical Endocrinologists medical guidelines for clinical practice for the diagnosis and treatment of acromegaly - 2011 update. Endocrine Practice 201117 (Supplement 4) 1-44. (https://doi.org/10.4158/ep.17.s4.1)

7 Giustina A, Chanson P, Kleinberg D, Bronstein MD, Clemmons DR, Klibanski A, van der Lely AJ, Strasburger CJ, Lamberts SW, Ho KK, et al. Expert consensus document: a consensus on the medical treatment of acromegaly. Nature Reviews: Endocrinology $2014 \mathbf{1 0}$ 243-248. (https://doi.org/10.1038/nrendo.2014.21)

8 Starke RM, Raper DM, Payne SC, Vance ML, Oldfield EH \& Jane JA, Jr. Endoscopic vs microsurgical transsphenoidal surgery for acromegaly: outcomes in a concurrent series of patients using modern criteria for remission. Journal of Clinical Endocrinology and Metabolism 201398 3190-3198. (https://doi.org/10.1210/jc.2013-1036)

9 Dorward NL. Endocrine outcomes in endoscopic pituitary surgery: a literature review. Acta Neurochirurgica 2010152 1275-1279. (https:// doi.org/10.1007/s00701-010-0649-y)

10 Bollerslev J, Heck A \& Olarescu NC. MANAGEMENT OF ENDOCRINE DISEASE: Individualised management of acromegaly. European Journal of Endocrinology 2019181 R57-R71. (https://doi.org/10.1530/ EJE-19-0124)

11 Antunes X, Ventura N, Camilo GB, Wildemberg LE, Guasti A, Pereira PJM, Camacho AHS, Chimelli L, Niemeyer P, Gadelha MR, et al. Predictors of surgical outcome and early criteria of remission in acromegaly. Endocrine 201860 415-422. (https://doi.org/10.1007/ s12020-018-1590-8)

12 Park SH, Ku CR, Moon JH, Kim EH, Kim SH \& Lee EJ. Age- and sexspecific differences as predictors of surgical remission among patients with acromegaly. Journal of Clinical Endocrinology and Metabolism 2018103 909-916. (https://doi.org/10.1210/jc.2017-01844)

13 Gadelha MR, Wildemberg LE, Bronstein MD, Gatto F \& Ferone D. Somatostatin receptor ligands in the treatment of acromegaly. Pituitary 201720 100-108. (https://doi.org/10.1007/s11102-0170791-0)

14 Colao A, Auriemma RS, Pivonello R, Kasuki L \& Gadelha MR. Interpreting biochemical control response rates with first-generation somatostatin analogues in acromegaly. Pituitary 201619 235-247. (https://doi.org/10.1007/s11102-015-0684-z)

15 Bernabéu I, Fajardo C, Marazuela M, Cordido F, Venegas EM, de Pablos-Velasco P, Maroto GP, Olvera MP, de Paz IP, Carvalho D, et al. Effectiveness of lanreotide autogel $120 \mathrm{mg}$ at extended dosing intervals for acromegaly. Endocrine 202070 575-583. (https://doi. org/10.1007/s12020-020-02424-z)

16 Colao A, Bronstein MD, Freda P, Gu F, Shen CC, Gadelha M, Fleseriu M, van der Lely AJ, Farrall AJ, Hermosillo Reséndiz K, et al. Pasireotide versus octreotide in acromegaly: a head-to-head superiority study. Journal of Clinical Endocrinology and Metabolism 201499 791-799. (https://doi.org/10.1210/jc.2013-2480)

17 Gadelha MR, Bronstein MD, Brue T, Coculescu M, Fleseriu M, Guitelman M, Pronin V, Raverot G, Shimon I, Lievre KK, et al. Pasireotide versus continued treatment with octreotide or lanreotide in patients with inadequately controlled acromegaly (PAOLA): a randomised, phase 3 trial. Lancet: Diabetes and Endocrinology 20142 875-884. (https://doi.org/10.1016/S2213-8587(14)70169-X)

18 Shimon I, Adnan Z, Gorshtein A, Baraf L, Saba Khazen N, Gershinsky M, Pauker Y, Abid A, Niven MJ, Shechner C, et al. Efficacy and safety of long-acting pasireotide in patients with somatostatinresistant acromegaly: a multicenter study. Endocrine 201862 448-455. (https://doi.org/10.1007/s12020-018-1690-5)

19 Gadelha M, Bex M, Colao A, Pedroza Garcia EM, Poiana C, JimenezSanchez M, Yener S, Mukherjee R, Bartalotta A, Maamari R, et al. Evaluation of the efficacy and safety of switching to pasireotide in patients with acromegaly inadequately controlled with firstgeneration somatostatin analogs. Frontiers in Endocrinology 201910 931. (https://doi.org/10.3389/fendo.2019.00931)

20 Colao A, Bronstein MD, Brue T, De Marinis L, Fleseriu M, Guitelman M, Raverot G, Shimon I, Fleck J, Gupta P, et al. Pasireotide for acromegaly: long-term outcomes from an extension to the Phase III PAOLA study. European Journal of Endocrinology 2020182583. (https://doi.org/10.1530/EJE-19-0762)

21 Melmed S, Bronstein MD, Chanson P, Klibanski A, Casanueva FF, Wass JAH, Strasburger CJ, Luger A, Clemmons DR \& Giustina A. A Consensus Statement on acromegaly therapeutic outcomes. Nature Reviews: Endocrinology 201814 552-561. (https://doi.org/10.1038/ s41574-018-0058-5)

22 Kasuki L, Dalmolin MD, Wildemberg LE \& Gadelha MR. Treatment escape reduces the effectiveness of cabergoline during long-term treatment of acromegaly in monotherapy or in association with firstgeneration somatostatin receptor ligands. Clinical Endocrinology 2018 88 889-895. (https://doi.org/10.1111/cen.13595)

23 Trainer PJ, Drake WM, Katznelson L, Freda PU, Herman-Bonert V, van der Lely AJ, Dimaraki EV, Stewart PM, Friend KE, Vance ML, et al. Treatment of acromegaly with the growth hormone-receptor antagonist pegvisomant. New England Journal of Medicine 2000342 1171-1177. (https://doi.org/10.1056/NEJM200004203421604)

24 Buchfelder M, van der Lely AJ, Biller BMK, Webb SM, Brue T, Strasburger CJ, Ghigo E, Camacho-Hubner C, Pan K, Lavenberg J, et al. Long-term treatment with pegvisomant: observations from 2090 acromegaly patients in acrostudy. European Journal of Endocrinology 2018179 419-427. (https://doi.org/10.1530/EJE-180616)

25 Boguszewski CL, Huayllas MKP, Vilar L, Naves LA, Ribeiro-Oliveira Junior A, Soares BS, Czepielewski MA, Abucham J, Correa-Silva SR, Bronstein MD, et al. Brazilian multicenter study on pegvisomant treatment in acromegaly. Archives of Endocrinology and Metabolism 201963 328-336. (https://doi.org/10.20945/2359-3997000000159)

26 Sandret L, Maison P \& Chanson P. Place of cabergoline in acromegaly: a meta-analysis. Journal of Clinical Endocrinology and Metabolism 201196 1327-1335. (https://doi.org/10.1210/jc.20102443)

27 Neggers SJ, de Herder WW, Janssen JA, Feelders RA \& van der Lely AJ. Combined treatment for acromegaly with long-acting somatostatin analogs and pegvisomant: long-term safety for up to 4.5 years (median 2.2 years) of follow-up in 86 patients. European Journal of Endocrinology 2009160 529-533. (https://doi.org/10.1530/EJE-080843)

28 Bernabeu I, Alvarez-Escola C, Paniagua AE, Lucas T, Pavon I, Cabezas-Agricola JM, Casanueva FF \& Marazuela M. Pegvisomant and cabergoline combination therapy in acromegaly. Pituitary 201316 101-108. (https://doi.org/10.1007/s11102-012-0382-z)

29 Neggers SJ, van Aken MO, de Herder WW, Feelders RA, Janssen JA, Badia X, Webb SM \& van der Lely AJ. Quality of life in acromegalic patients during long-term somatostatin analog treatment with and without pegvisomant. Journal of Clinical Endocrinology and Metabolism 200893 3853-3859. (https://doi.org/10.1210/jc.2008-0669)

30 Fernández-Pérez L, Guerra B, Díaz-Chico JC \& Flores-Morales A. Estrogens regulate the hepatic effects of growth hormone, a https://ec.bioscientifica.com https://doi.org/10.1530/EC-20-0433 (c) 2020 The authors Published by Bioscientifica Ltd

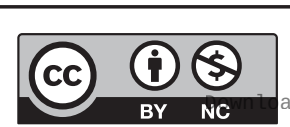

This work is licensed under a Creative Commons Attribution-NonCommercial 4.0 International License. ded from Bioscientifica.com at $04 / 26 / 2023$ 01:12:37PM 
hormonal interplay with multiple fates. Frontiers in Endocrinology 20134 66. (https://doi.org/10.3389/fendo.2013.00066)

31 Stone JC, Clark J, Cuneo R, Russell AW \& Doi SA. Estrogen and selective estrogen receptor modulators (SERMs) for the treatment of acromegaly: a meta-analysis of published observational studies. Pituitary 201417 284-295. (https://doi.org/10.1007/s11102-0130504-2)

32 Raverot G, Burman P, McCormack A, Heaney A, Petersenn S, Popovic V, Trouillas J, Dekkers OM \& Endocrinology ESo. European Society of Endocrinology Clinical Practice Guidelines for the management of aggressive pituitary tumours and carcinomas. European Journal of Endocrinology $2018 \mathbf{1 7 8}$ G1-G24

33 Gheorghiu ML. Updates in outcomes of stereotactic radiation therapy in acromegaly. Pituitary 201720 154-168. (https://doi. org/10.1007/s11102-016-0783-5)

34 Lee CC, Vance ML, Xu Z, Yen CP, Schlesinger D, Dodson B \& Sheehan J. Stereotactic radiosurgery for acromegaly. Journal of Clinical Endocrinology and Metabolism 201499 1273-1281. (https://doi. org/10.1210/jc.2013-3743)

35 Singh R, Didwania P, Lehrer EJ, Sheehan D, Sheehan K, Trifiletti DM \& Sheehan JP. Stereotactic radiosurgery for acromegaly: an international systematic review and meta-analysis of clinical outcomes. Journal of Neuro-Oncology 2020148 401-418. (https://doi. org/10.1007/s11060-020-03552-2)

36 Schöfl C, Franz H, Grussendorf M, Honegger J, Jaursch-Hancke C, Mayr B, Schopohl J \& participants of the German Acromegaly Register. Long-term outcome in patients with acromegaly: analysis of 1344 patients from the German Acromegaly Register. European Journal of Endocrinology 2013168 39-47. (https://doi.org/10.1530/ EJE-12-0602)

37 Kasuki L, Marques NV, Nuez MJ, Leal VL, Chinen RN \& Gadelha MR. Acromegalic patients lost to follow-up: a pilot study. Pituitary 2013 16 245-250. (https://doi.org/10.1007/s11102-012-0412-x)

38 Muhammad A, van der Lely AJ, Delhanty PJD, Dallenga AHG, Haitsma IK, Janssen JAMJL \& Neggers SJCMM. Efficacy and safety of switching to pasireotide in patients with acromegaly controlled with pegvisomant and first-generation somatostatin analogues (PAPE study). Journal of Clinical Endocrinology and Metabolism 2018103 586-595. (https://doi.org/10.1210/jc.2017-02017)

39 Urbani C, Sardella C, Calevro A, Rossi G, Scattina I, Lombardi M, Lupi I, Manetti L, Martino E \& Bogazzi F. Effects of medical therapies for acromegaly on glucose metabolism. European Journal of Endocrinology 2013169 99-108. (https://doi.org/10.1530/EJE-130032)

40 Muhammad A, Coopmans EC, Delhanty PJD, Dallenga AHG, Haitsma IK, Janssen JAMJL, van der Lely AJ \& Neggers SJCMM. Efficacy and safety of switching to pasireotide in acromegaly patients controlled with pegvisomant and somatostatin analogues: PAPE extension study. European Journal of Endocrinology 2018179 269-277. (https://doi.org/10.1530/EJE-18-0353)

41 Chiloiro S, Bima C, Tartaglione T, Giampietro A, Gessi M, Lauretti L, Anile C, Colosimo C, Rindi G, Pontecorvi A, et al. Pasireotide and pegvisomant combination treatment in acromegaly resistant to second-line therapies: a longitudinal study. Journal of Clinical Endocrinology and Metabolism 2019104 5478-5482. (https://doi. org/10.1210/jc.2019-00825)

42 Fricker G, Drewe J, Vonderscher J, Kissel T \& Beglinger C. Enteral absorption of octreotide. British Journal of Pharmacology 1992105 783-786. (https://doi.org/10.1111/j.1476-5381.1992.tb09057.x)

43 Tuvia S, Pelled D, Marom K, Salama P, Levin-Arama M, Karmeli I, Idelson GH, Landau I \& Mamluk R. A novel suspension formulation enhances intestinal absorption of macromolecules via transient and reversible transport mechanisms. Pharmaceutical Research 201431 2010-2021. (https://doi.org/10.1007/s11095-014-1303-9)

44 Tuvia S, Atsmon J, Teichman SL, Katz S, Salama P, Pelled D, Landau I, Karmeli I, Bidlingmaier M, Strasburger CJ, et al. https://ec.bioscientifica.com https://doi.org/10.1530/EC-20-0433 (c) 2020 The authors Published by Bioscientifica Ltd
Oral octreotide absorption in human subjects: comparable pharmacokinetics to parenteral octreotide and effective growth hormone suppression. Journal of Clinical Endocrinology and Metabolism 201297 2362-2369. (https://doi.org/10.1210/jc.20121179)

45 Melmed S, Popovic V, Bidlingmaier M, Mercado M, van der Lely AJ, Biermasz N, Bolanowski M, Coculescu M, Schopohl J, Racz K, et al. Safety and efficacy of oral octreotide in acromegaly: results of a multicenter phase III trial. Journal of Clinical Endocrinology and Metabolism 2015100 1699-1708. (https://doi.org/10.1210/jc.20144113)

46 Samson SL, Nachtigall LB, Fleseriu M, Gordon MB, Bolanowski M, Labadzhyan A, Ur E, Molitch M, Ludlam WH, Patou G, et al. Maintenance of acromegaly control in patients switching From injectable somatostatin receptor ligands to oral octreotide. Journal of Clinical Endocrinology and Metabolism 2020105 e3785-e3797. (https://doi.org/10.1210/clinem/dgaa526)

47 Kenakin T. Signaling bias in drug discovery. Expert Opinion on Drug Discovery 201712 321-333. (https://doi.org/10.1080/17460441.2017. 1297417)

48 Schonbrunn A. Selective agonism in somatostatin receptor signaling and regulation. Molecular and Cellular Endocrinology 2008286 35-39. (https://doi.org/10.1016/j.mce.2007.09.009)

49 Madan A, Zhu YF, Markison S, Betz S, Krasner A, Luo R, Oltersdorf T, Jochelson T, Lickliter J \& Struthers S. SAT-429 final results from the first in man Phase 1 clinical trial of CRN00808, an orally bioavailable sst2-selective, nonpeptide somatostatin biased agonist, for the treatment of acromegaly: safety, pharmacokinetics, pharmacodynamics, and midazolam drug interaction in healthy volunteers. Journal of the Endocrine Society 20193 (Supplement_1) SAT-429. (https://doi.org/10.1210/js.2019-SAT-429)

50 Dias N \& Stein CA. Antisense oligonucleotides: basic concepts and mechanisms. Molecular Cancer Therapeutics 20021 347-355.

51 Trainer PJ, Newell-Price JDC, Ayuk J, Aylwin SJB, Rees A, Drake W, Chanson P, Brue T, Webb SM, Fajardo C, et al. A randomised, openlabel, parallel group phase 2 study of antisense oligonucleotide therapy in acromegaly. European Journal of Endocrinology 2018179 97-108. (https://doi.org/10.1530/EJE-18-0138)

52 McClorey G \& Wood MJ. An overview of the clinical application of antisense oligonucleotides for RNA-targeting therapies. Current Opinion in Pharmacology 201524 52-58. (https://doi.org/10.1016/j. coph.2015.07.005)

53 Tachas G, Lofthouse S, Wraight CJ, Baker BF, Sioufi NB, Jarres RA, Berdeja A, Rao AM, Kerr LM, d'Aniello EM, et al. A GH receptor antisense oligonucleotide inhibits hepatic GH receptor expression, IGF-I production and body weight gain in normal mice. Journal of Endocrinology 2006189 147-154. (https://doi.org/10.1677/joe.1.06553)

54 Antisense Therapeutics Limited: ATL1103 successfully progresses towards Phase II clinical trial. Antisense.com (online). (available at: https://pipelinereview.com/index.php/2011120746504/DNA-RNAand-Cells/Antisense-Therapeutics-Limited-ATL1103-SuccessfullyProgresses-towards-Phase-II-Clinical-Trial.html2011)

55 Coopmans EC, Korevaar TIM, van Meyel SWF, Daly AF, Chanson P, Brue T, Delemer B, Hana V, Colao A, Carvalho D, et al. Multivariable prediction model for biochemical response to first-generation somatostatin receptor ligands in acromegaly. Journal of Clinical Endocrinology and Metabolism 2020 105. (https://doi.org/10.1210/ clinem/dgaa387)

56 Shen M, Zhang Q, Liu W, Wang M, Zhu J, Ma Z, He W, Li S, Shou X, Li Y, et al. Predictive value of T2 relative signal intensity for response to somatostatin analogs in newly diagnosed acromegaly. Neuroradiology 201658 1057-1065. (https://doi.org/10.1007/s00234016-1728-4)

57 Kasuki L, Vieira Neto L, Wildemberg LE, Colli LM, de Castro M, Takiya CM \& Gadelha MR. AIP expression in sporadic somatotropinomas is a predictor of the response to octreotide LAR

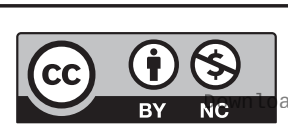

This work is licensed under a Creative Commons Attribution-NonCommercial 4.0 International License. ded from Bioscientifica.com at 04/26/2023 01:12:37PM 
therapy independent of SSTR2 expression. Endocrine-Related Cancer 201219 L25-L29. (https://doi.org/10.1530/ERC-12-0020)

58 Taboada GF, Luque RM, Neto LV, Machado EeO, Sbaffi BC, Domingues RC, Marcondes JB, Chimelli LM, Fontes R, Niemeyer P, et al. Quantitative analysis of somatostatin receptor subtypes (1-5) gene expression levels in somatotropinomas and correlation to in vivo hormonal and tumor volume responses to treatment with octreotide LAR. European Journal of Endocrinology 2008158 295-303. (https://doi.org/10.1530/EJE-07-0562)

59 Gadelha MR, Kasuki L \& Korbonits M. Novel pathway for somatostatin analogs in patients with acromegaly. Trends in Endocrinology and Metabolism 201324 238-246. (https://doi. org/10.1016/j.tem.2012.11.007)

60 Paragliola RM, Corsello SM \& Salvatori R. Somatostatin receptor ligands in acromegaly: clinical response and factors predicting resistance. Pituitary 201720 109-115. (https://doi.org/10.1007/ s11102-016-0768-4)

61 Kasuki L, Wildemberg LEA, Neto LV, Marcondes J, Takiya CM \& Gadelha MR. Ki-67 is a predictor of acromegaly control with octreotide LAR independent of SSTR2 status and relates to cytokeratin pattern. European Journal of Endocrinology 2013169 217-223. (https://doi.org/10.1530/EJE-13-0349)

62 Vieira Neto L, Taboada GF \& Gadelha MR. Somatostatin receptors subtypes 2 and 5, dopamine receptor type 2 expression and gsp status as predictors of octreotide LAR responsiveness in acromegaly. Arquivos Brasileiros de Endocrinologia and Metabologia 200852 1288-1295. (https://doi.org/10.1590/S000427302008000800014)

63 Kasuki L, Wildemberg LE \& Gadelha MR. MANAGEMENT OF ENDOCRINE DISEASE: Personalized medicine in the treatment of acromegaly. European Journal of Endocrinology 2018178 R89-R100. (https://doi.org/10.1530/EJE-17-1006)
64 Cuevas-Ramos D \& Fleseriu M. Pasireotide: a novel treatment for patients with acromegaly. Drug Design, Development and Therapy 2016 10 227-239. (https://doi.org/10.2147/DDDT.S77999)

65 Muhammad A, Coopmans EC, Gatto F, Franck SE, Janssen JAMJL, van der Lely AJ, Hofland LJ \& Neggers SJCMM. Pasireotide responsiveness in acromegaly is mainly driven by somatostatin receptor Subtype 2 expression. Journal of Clinical Endocrinology and Metabolism 2019104 915-924. (https://doi.org/10.1210/jc.2018-01524)

66 Coopmans EC, Schneiders JJ, El-Sayed N, Erler NS, Hofland LJ, van der Lely AJ, Petrossians P, Potorac J, Muhammad A \& Neggers SJCMM. T2-signal intensity, sstr expression, and somatostatin analogs efficacy predict response to pasireotide in acromegaly. European Journal of Endocrinology 2020182 595-605. (https://doi.org/10.1530/EJE-19-0840)

67 Kasuki L, Machado EdO, Ogino LL, Coelho MCA, Silva CMdS Wildemberg LEA, Lima CHA \& Gadelha MR. Experience with pegvisomant treatment in acromegaly in a single Brazilian tertiary reference center: efficacy, safety and predictors of response. Archives of Endocrinology and Metabolism $2016 \mathbf{6 0}$ 479-485. (https://doi. org/10.1590/2359-3997000000210)

68 Bernabeu I, Alvarez-Escola C, Quinteiro C, Lucas T, Puig-Domingo M, Luque-Ramirez M, de Miguel-Novoa P, Fernandez-Rodriguez E, Halperin I, Loidi L, et al. The exon 3-deleted growth hormone receptor is associated with better response to pegvisomant therapy in acromegaly. Journal of Clinical Endocrinology and Metabolism 201095 222-229. (https://doi.org/10.1210/jc.2009-1630)

69 Franck SE, Broer L, van der Lely AJ, Kamenicky P, Bernabéu I, Malchiodi E, Delhanty PJD, Rivadeneira F \& Neggers SJCMM. The effect of the Exon-3-deleted growth hormone receptor on pegvisomant-treated acromegaly: a systematic review and metaanalysis. Neuroendocrinology 2017105 131-140. (https://doi. org/10.1159/000448844)

Received in final form 16 October 2020

Accepted 28 October 2020

Accepted Manuscript published online 29 October 2020
This work is licensed under a Creative Commons Attribution-NonCommercial 4.0 International License. ded from Bioscientifica.com at 04/26/2023 01:12:37PM 